\title{
The Possibility of Using Winter Oilseed Rape (Brassica napus L. var. Napus) for Energy Purposes
}

\section{Możliwość wykorzystania rzepaku ozimego (Brassica napus L. var. Napus) do celów energetycznych}

\section{Jakub Siemek*, Jan Macuda*, Łukasz Łukańko*, Jakub Nowak**, Tadeusz Zając ${ }^{\star \star \star}$}

\author{
*AGH University of Science and Technology, Faculty of Drilling, Oil and Gas, \\ al. Mickiewicza 30, 30-059 Krakow, \\ **AGH University of Science and Technology, Faculty of Physics and Applied Computer \\ al. Mickiewicza 30, 30-059 Krakow, \\ *** University of Agriculture, Unit of Crop Production, Institute of Plant Production, \\ al. Mickiewicza 21, 31-120 Krakow, \\ E-mails (corresponding authors): siemek@agh.edu.pl,macuda@agh.edu.pl
}

\begin{abstract}
Biomass is an important element in the energy balance in the world and plays a large role in efforts to reduce greenhouse gas emissions, and by this is a sustainable source of energy. One method of using biomass is through co-firing with hard coal and lignite in order to generate electricity. An important factor promoting the use of biomass in European Union countries is the fact that $\mathrm{CO}_{2}$ emissions from combustion are not included in the sum of emissions from fuel combustion, in accordance with the principles established in the emission trading system EU ETS.

The aim of our research was to examine the possibility of using winter oilseed rape for energy purposes, grown in three research centres located in southern Poland. Two varieties of winter oilseed rape, Adam and Poznaniak, were used during laboratory tests. Analyses were carried out for siliques, seeds, and the main and lateral stem. As part of the study, the calorific value and heat of combustion were determined for 20 samples of winter oilseed rape. The highest values were obtained for seeds, while the lowest were obtained for stems. The calculated values of carbon dioxide emissions factor for the analysed samples were in most cases above $100 \mathrm{~kg} / \mathrm{GJ}$ and were much higher than the emission during hard coal combustion.

In addition, as part of the study, the biomass moisture, amount of ash generated in the combustion process, and the content of volatile compounds as well as carbon and sulphur were determined.
\end{abstract}

Key words: biomass, winter oilseed rape, co-firing, calorific value, carbon dioxide emission

\section{Streszczenie}

Biomasa jest istotnym elementem w bilansie energetycznym na świecie i odgrywa dużą rolę w działaniach na rzecz redukcji emisji gazów cieplarnianych, stanowiąc zrównoważone źródło energii. Jednym ze sposobów użycia biomasy jest jej współspalanie z węglem kamiennym i brunatnym w celu wytwarzania energii elektrycznej. Ważnym czynnikiem promującym wykorzystanie biomasy w państwach Unii Europejskiej jest fakt, że emisja $\mathrm{CO}_{2} \mathrm{z}$ jej spalania nie wlicza się do sumy emisji ze spalania paliw, zgodnie z zasadami ustalonymi w systemie handlu uprawnieniami EU ETS.

Celem badań było zbadanie możliwości wykorzystania rzepaku ozimego do celów energetycznych, wychodowanego w trzech lokalizacjach Polski południowej. Do badań wykorzystane zostały dwa gatunki rzepaku ozimego Adam i Poznanianki, analizy wykonano dla łuszczyny, nasion, łodygi głównej i bocznej. W ramach przeprowadzonych badań określona została wartość opałowa oraz ciepło spalanie dla 20 próbek rzepaku ozimego. Najwyższe 
wartości zostały uzyskane dla ziaren rzepaku, natomiast najniższe dla łodyg. Obliczone wartości emisji dwutlenku węgla dla badanych próbek w większości przypadków wynosiły powyżej $100 \mathrm{mg} / \mathrm{kJ}$ i były dużo większe niż emisja podczas spalania węgla kamiennego i brunatnego. Dodatkowo w ramach badania oznaczono wilgotność biomasy, ilość powstałego w procesie spalania popiołu oraz oceniono zawartość części lotnych oraz węgla i siarki. Ponadto w ramach badania wykonano pomiary wilgotność biomasy, ilość wytworzonego popiołu w procesie spalania oraz określono zawartość związków lotnych oraz węgla i siarki.

Slowa kluczowe: biomasa, rzepak ozimy, wartość opałowa, emisja ditlenku węgla

\section{Introduction}

In 2015, the General Assembly of the United Nations introduced resolutions on Transforming our world: the 2030 Agenda for Sustainable Development. This document presented 17 goals for Sustainable Development and 169 related tasks (UN, 2012). One agenda goal is to provide all people with a healthy life and adequate quality of living in order to significantly reduce the number of deaths and illnesses caused by atmospheric air pollution. Another important goal of the agenda is to provide everyone with access to sources of stable, sustainable and modern energy. Currently, however, about 3 billion people in the world depend on energy produced from coal or wood. Therefore, the main objective for 2030 is to significantly increase the share of renewable energy sources. Additionally, in 2015, The European Commission presented its strategic approach to sustainable development for 2015-2019 and its strategy until 2030. One of its priorities is safer, more affordable and more sustainable energy. Actions taken by EU members are to be aimed at reducing greenhouse gas emissions and increasing the development of renewable energy sources. In 2012, the European Commission also released a document entitled Innovating for Sustainable Growth: A Bioeconomy for Europe. Here, a strategy for the sustainable use of renewable resources in the European economy is emphasized. Therefore, a new examination of sectors related to food and energy production is necessary. Actions taken in this area are to ensure food security for people, sustainable management of natural resources, use of biomass for energy purposes, mitigation of climate change by developing new ways of generating electricity and reducing greenhouse gas emissions (EC, 2012).

One of the strategic goal of economic policy is to strive for sustainable development of the country. One way that this is implemented is by providing the domestic economy with a safe and competitive energy supply, while simultaneously improving the condition of the environment, taking into account the increasingly restrictive laws regarding the reduction of $\mathrm{CO}_{2}$ emissions.

Currently, one of the most important environmental problems in the world is air pollution, which has a significant negative impact on human health and quality of life.

It is known that electricity generation is the main cause of climate change and accounts for about $60 \%$ of global greenhouse gas emissions. The reduction of coal usage in energy production is a key and longterm goal of climate policy.

Air pollution is mainly caused by the low emission of harmful substances that arise during ineffective combustion of hard coal in households (Zhang et al., 2015). High emission also has a significant negative impact on air quality, resulting from the combustion of hard coal and lignite pn power plants (Goto et al., 2013; IEA, 2017; Pawłowski and Pawłowski 2016). Carbon dioxide from coal combustion processes has a significant impact on climate change, and consequently, serves to increase the global atmospheric temperature (Gustavsson et al., 2010).

According Eurostat, in 2016, the entire EU energy sector generated 1218.8 thousand tonnes of sulphur dioxide, 1311.0 thousand tonnes of nitrogen oxides and 99.8 thousand tonnes of particulates. In addition, 327.9 million tonnes of carbon dioxide were emitted into the atmosphere (Eurostat, Air 2019 a,b).

One of the countries, where energy sector is based on coal is Poland. According to the Polish Central Statistical Office, hard coal and lignite combustion processes from power stations and heat and power stations emitted 369.15 thousand tonnes of sulphur dioxide, 205.49 thousand tonnes of nitrogen oxides, 47.15 thousand tonnes of carbon monoxide, and 28.05 thousand tonnes of particulate matter into the atmosphere in 2015 (Central Statistical Office, 2017). In Poland, almost 162.7 milion tonnes of carbon dioxide were emitted into the atmosphere from the entire energy industry in 2015 (Central Statistical Office, 2017). Such a large emission contributes significantly to the increase in air pollution in Poland, which according to recent research is one of the worst in Europe (EEA, 2018). During energy production, pollutant emissions can be reduced by co-firing biomass with coal (Agbor et al., 2014; Dzikuc and Piwowar, 2016; Chen et al., 2017). This is in line with objectives of the climate and energy package, which calls for increasing energy production from renewable sources. Directive 2009/28/EC, on the promotion of the use of energy from renewable sources, states that by 2020 , the amount of energy from renewable sources for most EU countries should be $20 \%$, while for Poland should be 15\% (Directive 2009/28/EC). Renewable energy sources, including biomass, are becoming an important component of energy balance in European countries and play a key role in reducing greenhouse gas emissions (Cao and 
Pawłowski, 2013). Biomass, the third largest energy resource in the in the world, is a natural source of energy classified as renewable and can be a significant substitute for fossil fuels, especially that of hard coal or lignite (Tumuluru et al., 2010).

According to Eurostat, in 2017, the European Union generated almost $94674.3 \mathrm{GWh}$ of energy from primary solid biofuels. The largest producers of energy from primary solid biofuels were The United Kingdom (20 762.5 GWh), Finland (10 890 GWh), Germany (10 $657 \mathrm{GWh})$ and Sweden (10 $250 \mathrm{GWh})$ (Eurostat, 2019). In Poland in 2016, the amount of energy generated from biomass was $3350 \mathrm{GWh}$, but in installations using biomass co-fired with other fuels, the amount generated was only $1000 \mathrm{GWh}$ (Energy Regulatory Office, 2018). Combustion used both for the production of thermal energy and electricity is the most common and simplest method of obtaining energy from biomass (McKendry, 2002). Biomass can be co-fired with coal in a direct way, in open or closed furnaces, or indirectly - in the initial gasification of biomass in separate gasifiers, and then through combustion of the obtained gas, e.g. in boilers or combustion engines (Al-Mansour and Zuwala, 2010). Biomass mainly includes waste products from forestry, the wood industry, urban public utilities, and agriculture, including dedicated energy crops of trees and oilseed rape (Vassilev et al., 2015). The most important properties characterizing biomass as fuel are the heat of combustion and the calorific value (Lestander et al. 2009; Erol et al., 2010; Bajwa et al., 2018). Biomass is characterized by lower thermal properties than hard coal, while the ecological effect of its combustion is much more beneficial (Mitchell et al., 2016; Vicente and Alves, 2018). Solid biomass consists of combustible mass and ballast, which is composed of ash and water (Jandacka et al., 2015). High moisture content is a disadvantage to the use of biomass as fuel, due to hinderance of ignition, reduction of calorific value, and contribution to corrosion of the installation (Demirbas, 2007). A very important feature of biomass is the content of volatile compounds, which are largely responsible for its calorific value (Emerhi, 2011). Volatile compounds are gases produced during fuel heating, created in the first phase of combustion due to the decomposition of thermally unstable organic particles of the combustible mass. Calorific values of biomass (depending on the plant species, moisture content, and method of storage) range from 15.41 to 19.52 MJ/kg (Erol et.al., 2010; Vassilev et al., 2015; Ozyuguran and Yaman, 2017). Despite the fact that $\mathrm{CO}_{2}$ emission from biomass combustion is higher than from coal combustion, it is not included in the sum of emissions from fuel combustion, in accordance with principles set out in the emissions trading system and the IPCC (Wielgosiński et al., 2017; EC, 2017). This approach is equivalent to the application of a zero emission factor for biomass.
The $\mathrm{CO}_{2}$ emission factor for coal combustion in Polish power plants is $92.30 \mathrm{~kg} / \mathrm{GJ}$ while for lignite the number is $110.77 \mathrm{~kg} / \mathrm{GJ}$ (Polish Institute of Environment Protection, 2016). In reference to IPCC 2006 guidelines, the $\mathrm{CO}_{2}$ emission factor for hard coal is $94.6 \mathrm{~kg} / \mathrm{GJ}$, for anthracite coal $98.3 \mathrm{~kg} / \mathrm{GJ}$ while for lignite $101.0 \mathrm{~kg} / \mathrm{GJ}$ (IPPC, 2006).

One of the sources of biomass which can be used for energy purposes is winter oilseed rape. Currently, seeds are widely used in the production of biofuels, but it can also be used in power plants for co-firing with hard coal and lignite. The calorific value of rape straw varies from 15.8 to $19.1 \mathrm{MJ} / \mathrm{kg}$, while the seeds have a calorific value as high as $26.6 \mathrm{MJ} / \mathrm{kg}$ (EA, 2016). In recent years, the production of winter oilseed rape significantly increased in Western Europe from $1.9 \mathrm{t} / \mathrm{ha}$ in 1965 to $3.1 \mathrm{t} / \mathrm{ha}$ in 2013 (Zając et al., 2016). In the European Union, in 2015, winter oilseed rape was grown on a total area of $6.465 \times 10^{6}$ ha, from which $21.7 \times 10^{6}$ tonnes of crops were collected (Eurostat, 2018). The largest producers of winter oilseed rape in the European Union are Germany, France, Poland, Romania and the UK (Table $1)$. Due to its large production in Poland, its widespread use in the co-firing process for the production of electric and thermal energy is justified. This solution can play an important role in the reduction of air pollution.

Table1. Main producer of winter rape (1000 t) in Europan Union 2017-2018 (Eurostat Statistics Crop production, 2019).

\begin{tabular}{|c|c|c|}
\hline Producer & 2017 & 2018 \\
\hline European Union & 21913.61 & 19938.53 \\
\hline Grmany & 4275.60 & 3677.20 \\
\hline France & 5378.51 & 4945.59 \\
\hline Poland & 2697.26 & 2163.20 \\
\hline Romania & 1673.33 & 1610.09 \\
\hline United Kigndom & 2167.00 & 2074.00 \\
\hline
\end{tabular}

\section{Experimental}

\subsection{Materials}

In order to conduct laboratory tests to determine the possibility of using biomass co-fired with hard coal or lignite in industrial power plants, two varieties of winter oilseed rape, Adam (Ada) and Poznaniak (Poz), were examined. Samples were collected from research centres: Głubczyce (GLU), Pawłowice (PAW) and Prusy (PRU), located in the south of Poland. These research centres belong to the Unit of Crop Production at the University of Agriculture in Krakow. Individual elements of the plant were analyzed: siliques ( $\mathrm{Si}$ ), seeds (Se), main stem (Ms), and lateral stem (Ls).

\subsection{Analysis}

Research of winter oilseeds rape was carried out at the Faculty of Drilling, Oil and Gas, at AGH University of Science and Technology in Krakow. All analyses were carried out in accordance with ISO 
standards. The provided samples of individual parts of winter oilseed rape were ground on a mill to the size required for laboratory tests. Verification of fragmentation was carried out using a laboratory sieve with a mesh size of $0.4 \mathrm{~mm}$. The crushed material was divided into laboratory samples for technical and elemental analysis.

In terms of technical analysis, the following analyses were made: elemental moisture (W), ash content (A) and volatile matter (V), heat of combustion value $(\mathrm{Hs})$ and calorific value $(\mathrm{Hi})$. Technical analysis to determine ash content, volatiles, and analytical moisture was carried out using automatic thermogravimetry ELTRA, during three stages of testing. In the first stage, the analytical moisture content was determined at a temperature of $105^{\circ} \mathrm{C}$, in the second stage, ash content was determined at $815^{\circ} \mathrm{C}$, and in the final stage, volatile compounds were determined at $850^{\circ} \mathrm{C}$. The last part of the technical analysis was determination of the heat of combustion, which was carried out using the LECO AC 350 adiabatic calorimeter. Each analysis was carried out on a sample weight of about $0.7 \mathrm{~g}$. What is slightly smaller than typically for coals $(0.8-1.5 \mathrm{~g})$ due to the much higher content of volatile compounds and difficulties with maintaining the tightness of the calorimetric bomb (firing the gasket) in several consecutive determinations. Prepared samples were weighed with an accuracy of $0.0002 \mathrm{~g}$ and were placed in a calorimetric bomb filled with oxygen at a pressure of $2.5 \mathrm{MPa}$. The test duration was 10 minutes and was divided into three stages: stabilization of conditions after the start of measurement, combustion, and measurement of thermal effects resulting from combustion of the biomass sample.

Based on the obtained results of the determination of the heat of combustion, moisture, and hydrogen content, the calorific value of the supplied samples of winter oilseed rape was calculated according to the formula (Maj et al., 2017):

$H_{i}^{a}=H_{S}^{a}-24.43 \cdot\left(W^{a}+8.94 \cdot H^{a}\right)$

where:

$H_{i}{ }^{a}$ - calorific value in the analytical state, $\mathrm{kJ} / \mathrm{kg}$,

$H_{S}{ }^{a}$ - heat of combustion in the analytical state, $\mathrm{kJ} / \mathrm{kg}$,

$W^{a}$ - analytical moisture of fuel sample, $\%$,

$H^{a}$ - hydrogen content in the analytical sample, \%,

24.43 - heat of water vaporization at a temperature of $25^{\circ} \mathrm{C}$ corresponding to $1 \%$ of water in fuel, $\mathrm{kJ} / \mathrm{kg}$, 8.94 - calculation coefficient of hydrogen content into water.

In addition, elemental analysis was carried out, which included determination of carbon (C), hydrogen $(\mathrm{H})$, and sulphur $(\mathrm{S})$ content. Elemental analysis of biomass samples were made using the ELTRA CHS-580 analyzer. The sample weight in each case was $0.3 \mathrm{~g}$. The research was carried out in a tube furnace where the temperature reached $1450^{\circ} \mathrm{C}$. The analysis time of a single sample is not specified. It is interrupted if the signal from all detectors drops to zero.

\subsection{Calculation of carbon dioxide emissions factor}

The last stage of the study was to determine $\mathrm{CO}_{2}$ emissions factor from the combustion process of winter oilseed rape samples. The combustion of fuels produces greenhouse gases such as carbon dioxide $\left(\mathrm{CO}_{2}\right)$, methane $\left(\mathrm{CH}_{4}\right)$ and nitrous oxide $\left(\mathrm{N}_{2} \mathrm{O}\right)$. Carbon occures in gases other than $\mathrm{CO}_{2}$ that are also emitted from combustion processes, including methane $\left(\mathrm{CH}_{4}\right)$, carbon monoxide $(\mathrm{CO})$, and nonmethane volatile organic compounds (NMVOCs). In the atmosphere, these gases are naturally oxidized to $\mathrm{CO}_{2}$ within a few days to 12 years, therefore they included to the net addition of $\mathrm{CO}_{2}$ to the atmosphere from fuel combustion (Gillenwater, 2005). Additionally, for typical stationary combustion processes, the total amount of carbon in gases other than carbon dioxide is much less than 1 percent of that contained in the $\mathrm{CO}_{2}$. This emission factor was calculated in accordance with the formula (Gillenwater, 2005):

$E=\frac{C}{H_{i}} \cdot f_{o x} \cdot \frac{M_{C O 2}}{M_{C}}$,

where:

$E-\mathrm{CO}_{2}$ emission factor $\mathrm{kg} / \mathrm{GJ}$,

$C$ - carbon content $\%$,

$H_{\mathrm{i}}-$ calorific value $\mathrm{kJ} / \mathrm{kg}$,

$f_{o x}$ - oxidation factor to account for fraction of carbon in fuel that remains as soot or ash (in the calculations assumed as 1),

$\mathrm{M}_{\mathrm{CO}_{2}}$ - molar mass of carbon dioxide $\mathrm{kg} / \mathrm{mol}$,

$M_{C}$ - molar mass of carbon $\mathrm{kg} / \mathrm{mol}$.

\section{Results and discusion}

The results of technical and elementary analysis, as well as calculation of the carbon dioxide emission from combustion from individual elements of two winter oilseed rape species are presented in Table 2. In order to investigate the possibility of using winter oilseed rape for energy production purposes, samples of winter oilseed rape were examined for ballast (elemental moisture content and ash).The elemental moisture content ranged from 3.4 to $16.0 \%$ for analysed samples. The lowest value was noted for seeds, while the highest was seen in siliques of both rapeseed cultivars. Samples with the lowest moisture content were also characterised by the lowest ash content. The lowest ash content was observed in seeds, and its amount varied from $3.3-5.6 \%$. The largest amount of ash was noted, as in the case of elemental moisture in siliques, to range from 7.5 to $13.0 \%$.

The next step in our study was the measurement of volatile compounds in the tested samples of winter oilseed rape. The lowest value of volatile compounds was seen in siliques, which ranged from 68.3 to 


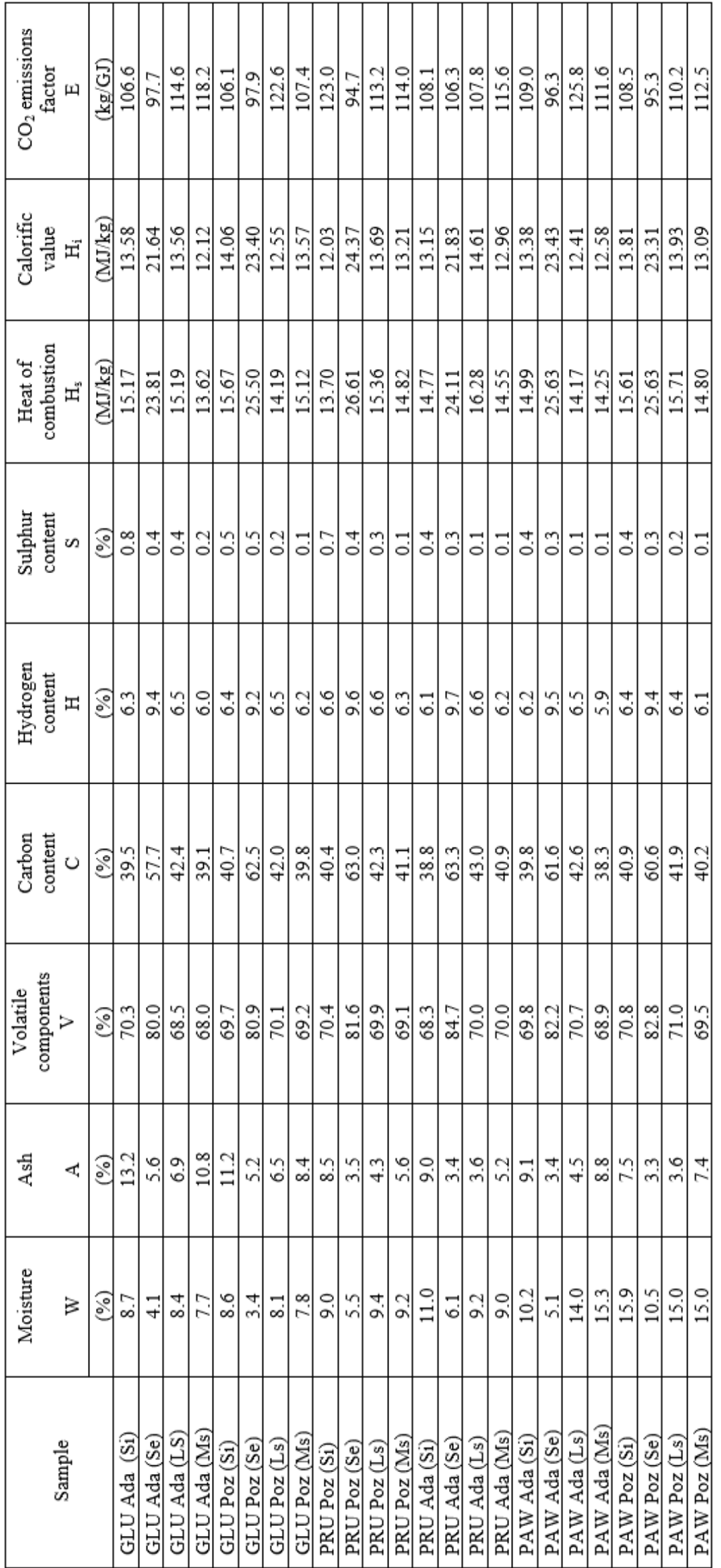

Table 2. Results of technical and elemental analisys of winter oilseed rape 


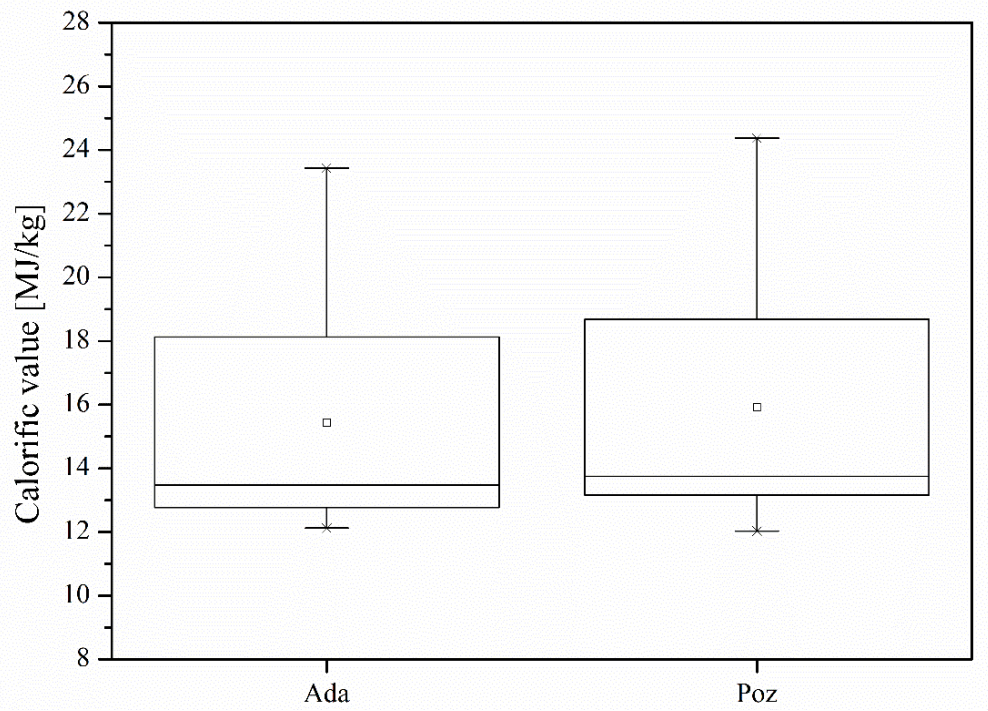

Figure 1. Calculated calorific value for the examined winter oilseed rape

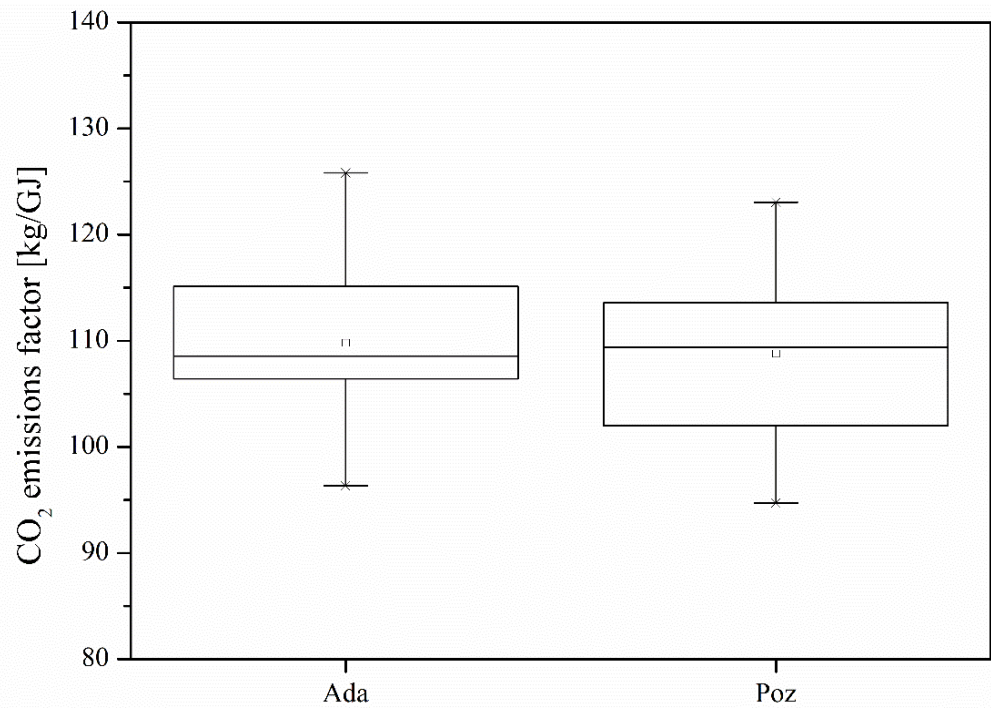

Figure 2. Calculated $\mathrm{CO}_{2}$ emission factor for the examined winter oilseed rape

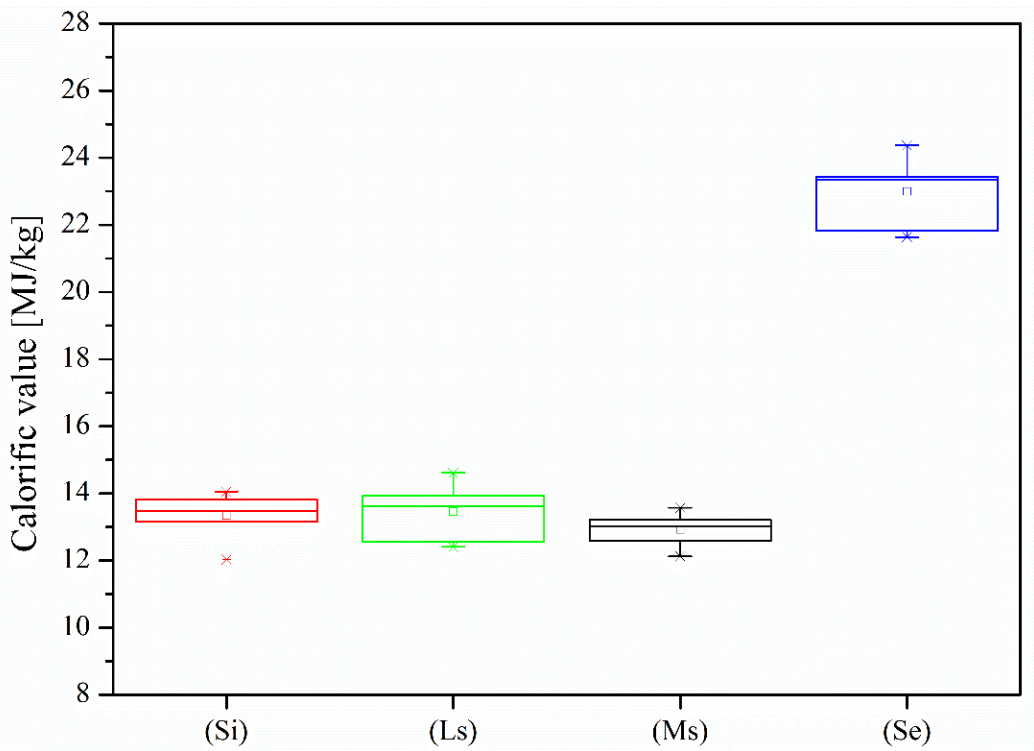

Figure 3. Calculated calorific value for difrent parts of examined winter oilseed rape 


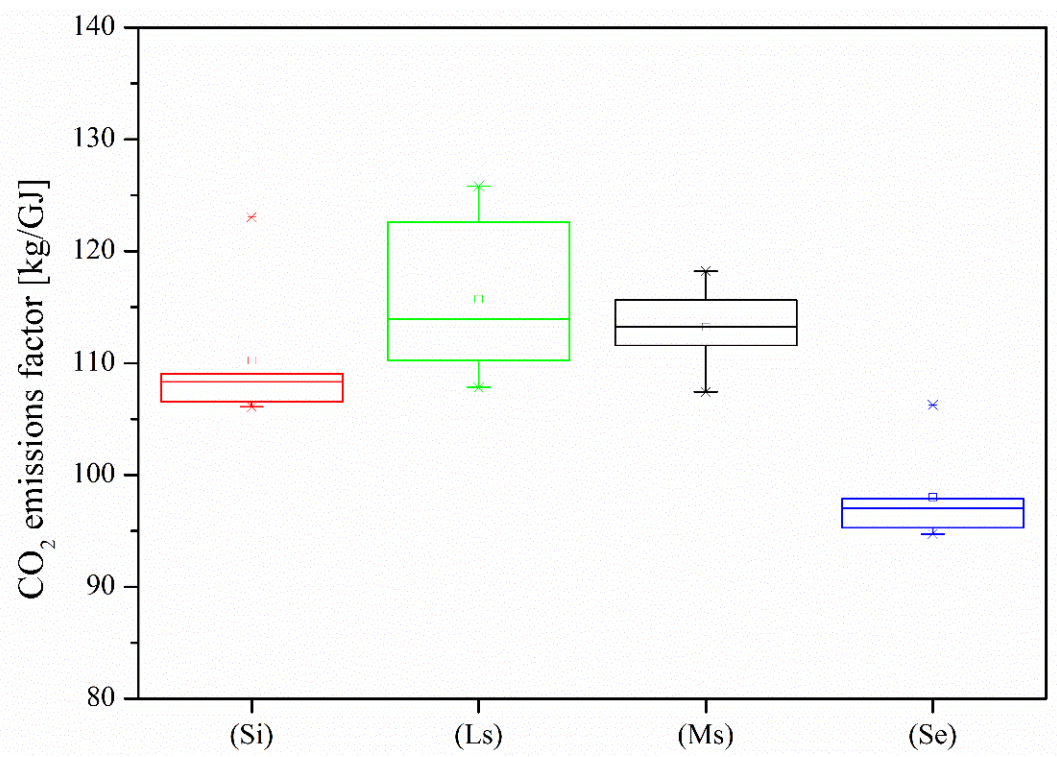

Figure 4. Calculated $\mathrm{CO}_{2}$ emission factor for difrent parts of examined winter oilseed rape

$70.3 \%$, while the highest was observed in grains, ranging from 80 to $84.7 \%$. The carbon content in the samples tested ranged from 38.3 to $63.3 \%$, hydrogen from 5.9 to $9.7 \%$, and sulphur from 0.050 to $0.86 \%$. Again, the highest content of coal and hydrogen was contained in seeds, while the lowest was in the siliques of winter oilseed rape samples.

The heat of combustion of the tested samples of winter oilseed rape ranged from 13.6 to $26.6 \mathrm{MJ} / \mathrm{kg}$, while the calorific value ranged from 12.0 to 24.4 $\mathrm{MJ} / \mathrm{kg}$. Calculated $\mathrm{CO}_{2}$ emission factors ranged from 94.7 to $125 \mathrm{~kg} / \mathrm{GJ}$. Between two species of winter oilseed rape, there were no significant differences in heating value and $\mathrm{CO}_{2}$ emissions, as illustrated in figures 1,2 . A significant difference in the heating value, heat of combustion, and $\mathrm{CO}_{2}$ emissions was seen between individual plant components. Siliques, main stem, and lateral stems of both winter rape species were characterised by a lower calorific value (12.0 to $14.6 \mathrm{MJ} / \mathrm{kg}$ ) and higher $\mathrm{CO}_{2}$ emission rates (106 to about $126 \mathrm{~kg} / \mathrm{GJ}$ ) in comparison with seeds. In the case of seeds, the calorific value varied from 21.6 to $24.4 \mathrm{MJ} / \mathrm{kg}$, and $\mathrm{CO}_{2}$ emissions varied from 94.7 to $97.9 \mathrm{~kg} / \mathrm{GJ}$ (Figure 3, Figure 4).

Our analyses show a relationship between the heat of combustion, calorific value, content of volatile compounds, elemental moisture, and ash in the samples of winter oilseed rape. For winter oilseed rape samples containing the largest amount of carbon, the highest value of heat was released and the lowest emission factor was measured. The highest heat of combustion and calorific value was seen in samples which had the lowest moisture content and amount of ash, as well as the highest content of volatile compounds. At the same time, $\mathrm{CO}_{2}$ emission factors were the lowest for these samples.

\section{Conclusion}

The research shows that winter oilseed rape is characterised by a relatively high calorific value (about $20 \mathrm{MJ} / \mathrm{kg}$ ), which is similar to the value for hard coal and lignite. The significantly lower calorific value (less than $14 \mathrm{MJ} / \mathrm{kg}$ ) of other winter oilseed rape components and their weaker parameters (above all high humidity - over 9\%) suggest that only seeds should be used as fuel for energy purposes. At the same time, the extensive use of seeds for energy purposes in accordance with the applicable regulations would contribute to a significant improvement of the $\mathrm{CO}_{2}$ emission balance for the so-called high emissions. The results of our research confirm earlier work carried out for culms of cereals, which suggested that there were no differences in energy parameters between particular species of a given plant (Zając et al., 2017). This suggests that in the case of crops for energy purposes, winter rape should be used, as they provide the highest yield for the given agricultural conditions.

According to the Polish Central Statistical Office, the average share of seeds in one tonne of the harvest index of winter oilseed rape is around $40 \%$. In order to limit the production of rape straw (rape straw is useless for food purposes), high-mowing is used during the harvest, which at the same time would raise the harvest index. Rape straw can be used for the production of pellets or for direct combustion in small heating plants using boilers adapted for burning biomass of relatively high humidity.

It should be noted that in the case of large scale use of winter oilseed rape, the area devoted to crops for food would be reduced, which could contribute to increasing food prices. 


\section{Acknowledgements}

This work was supported by the Ministry of Science and Higher Education, project No. 16.16.190.779 and 16.16.220.842 B02' and National Science Center NN310 169139.

\section{References}

3 AGBOR E., ZHANG X., KUMAR A., 2014, A review of biomass co-firing in North America, in: Renewable \& Sustainable Energy Reviews, 40, p. 930-943.

4 AL-MANSOUR F., ZUWALA J., 2010, An evaluation of biomass co-firing in Europe, in: Biomass \& Bioenergy, 34, p. 620-629.

5 BAJWA D.S., PETERSON T., SHARM N., SHOJAEIARANI J., BAJWA S.G., 2018, A review of densified solid biomass for energy production, in: Renewable \& Sustainable Energy Reviews, 96, p. 295-305.

6 CAO Y., PAWŁOWSKI A., 2013, Biomass as an answer to sustainable energy. Opportunity versus challenge, in: Environment Protection Engineering, 39(1), p. 153-161.

7 CENTRAL STATISTICAL OFFICE (GUS), 2017, Poland Environment, Warsaw.

8 CHEN C., QIN S., CHEN F., LU Z., CHENG Z., 2019, Co-combustion characteristics study of bagasse, coal and their blends by thermogravimetric analysis, in: Journal of the Energy Institute, 92(2), p. 364-369.

9 DEMIRBAS A., 2007, Effects of moisture and hydrogen content on the heating value of fuels, in: Energy Sources, Part A: Recovery, Utilization and Environmental Effects, 29, p. 649-655.

10 DZIKUC M., PIWOWAR A., 2016, Ecological and economic aspects of electric energy production using the biomass co-firing method: the case of Poland, in: Renewable \& Sustainable Energy Reviews, 55, p. 856-862.

11 EMERHI E.A., 2011, Physical and combustion properties of briquettes produced from sawdust of three hardwood species and different organic binders, in: Advances in Applied Science Research, 2, p. 236246.

12 ENERGY REGULATORY OFFICE, 2018, Energy consumption in Poland 2005-2018, Warsaw.

13 EA (ENVIRONEMNTAL AGENCY), 2016, Material comparators for end-of-waste decision,. Fuels: biomass, Report - SC130040/R7, Bristol.

14 EROL M., HAYKIRI-ACMA H., KUCUKBAYRAK S., 2010, Calorific value estimation of biomass from their proximate analyses data, in: Renewable Energy, 35, p.170-173.

15 EC (EUROPEAN COMMISSION), 2012, DIRECTORATE-GENERAL FOR RESEARCH AND INNOVATION, Innovating for sustainable growth: A bioeconomy for Europe, Brussels.

16 EC (EUROPEAN COMMISSION), 2017, Biomass issues in the EU ETS, Guidance Document, Brussels.

17 EEA (EUROPEAN ENVIRONMENTAL AGENCY), 2018, Air quality in Europe - 2018 report, Copenhagen.

18 EU (EUROPEAN UNION), 2009, Directive 2009/ 28/EC of The European Parliament and of The Council of 23 April 2009 on the promotion of the use of energy from renewable sources and amending and subsequently repealing Directives 2001/77/EC and 2003/30/EC, in: Off J. European Union, p. 16-62.

19 EUROSTAT, AIR EMISSION, 2019a, Greenhouse gas emissions by source sector, http://appsso.eurostat.ec.europa.eu/nui/show.do?dataset=env_air_gge \&lang=en (16.07.2019).

20 EUROSTAT, AIR EMISSION 2019b, Air pollutants by source sector, $\mathrm{http} / / /$ appsso.eurostat.ec.europa.eu/ nui/submitViewTableAction.do (16.07.2019).

21 EUROSTAT CROP PRODUCER, 2019, Crop production, http://appsso.eurostat.ec.europa.eu/nui/sub mitViewTableAction.do (30.05.2019).

22 EUROSTAT ENERGY, 2019, Production of electricity and derived heat by type of fuel 2019, Crop production, http://appsso.eurostat.ec.europa.eu/nui/ submitViewTableAction.do (30.05.2019).

23 EUROSTAT STATISTICS EXPLAINED, 2018, Main annual crop statistic, https://ec.europa.eu/euro stat/statistics-explained/index.php/Main_annual_cro p_statistics, (4.12.2018).

24 GILLENWATER M., 2005, Calculation Tool for Direct Emissions from Stationary Combustion version 3.0, in: Environmental Resources Trust, Washington DC.

25 GOTO K., YOGO K., HIGASHII T., 2013, A review of efficiency penalty in a coal-fired power plant with post-combustion $\mathrm{CO}_{2}$ capture, in: Applied Energy, 111, p. $710-720$.

26 GUSTAVSSON L., JOELSSON A., SATHRE R., 2010, Life cycle primary energy use and carbon emission of an eight-storey, in: Energy and Buildings, 42, p. 230-242.

27 INTERGOVERNMENTAL PANEL ON CLIMATE CHANGE, 2006, IPCC Guidelines for National Greenhouse Gas Inventories, ed. Eggleston S. et al., Inst. Global Environ. Strategies, Hayama.

28 IEA (INTERNATIOANAL ENERGY AGENCY), 2017, $\mathrm{CO}_{2}$ emissions from fuel combustion highlights $\left(2017^{\text {th }}\right.$ ed.), IEA/OECD, Paris.

29 JANDACKA J., MALCHO M., OCHODEK T., KOLONICNY J., HOLUBCIK M., 2015, The increase of silver grass ash melting temperature using additives, in: International Journal of Renewable Energy Research, 5, p. 258-265.

30 LESTANDER T.A., JOHNSSON B., GROTHAGE M., 2009, NIR techniques create added values for the pellet and biofuel industry, in: Bioresource Technology, 100(4), p. 1589-1594.

31 MAJ G., KRZACZEK P., KURANC A., PIEKARSKI W., 2017, Energy properties of sunflower seed husk as industrial extrusion residue, in: Research in Agricultural Engineering, 21, p. 7784.

32 MCKENDRY P., 2002, Energy production from biomass (Part I): overview of biomass, in: Bioresource Technology, 83 p. 37-46.

33 MITCHELL E.J.S., LEA-LANGTON A.R., JONES J.M., WILLIAMS A., LAYDEN P., JOHNSON R., 2016, The impact of fuel properties on the emissions from the combustion of biomass and other solid fuels in a fixed bed domestic stove, in: Fuel Processing Technology, 142 p. 115-123.

34 OZYUGURAN A., YAMAN S., 2017, Prediction of Calorific Value of Biomass from Proximate Analysis, in: Energy Procedia, 107, p. 130-136. 
35 PAWŁOWSKI L. PAWŁOWSKI A., 2016, Wpływ sposobów pozyskiwania energii na realizację paradygmatów zrównoważonego rozwoju, in: Rocznik Ochrona Środowiska/Annual Set Environment Protection, 18(2), p. 19-37.

36 POLISH INSTITUTE OF ENVIRONMENT PROTECTION, 2016, Calorific value an $\mathrm{CO}_{2}$ emission Factor, Emissions Trading System (EU ETS), Warsaw.

37 TUMULURU J.S., WRIGHT C.T., KENNY K.L., HESS J.R., 2010, A review on biomass densification technologies for energy application, Idaho Natl. Lab., Idaho.

38 VASSILEV S., VASSILEVA C., VASSILEV V., 2015, Advantages and disadvantages of composition and properties of biomass in comparison with coal: an overview, in: Fuel, 158, p. 330-350.

39 VICENTE E.D., ALVES C.A., 2018, An overview of particulate emissions from residential biomass combustion, in: Atmospheric Research, 199, p. 159185.

40 WIELGOSIŃSKI G., ŁECHTAŃSKA P., NAMIECIŃSKA O., 2017, Emission of some pollutants from biomass combustion in comparison to hard coal combustion, in: Journal of the Energy Institute, 90, p. 787-796.

41 UN: UNITED NATIONS' DIVISION FOR SUSTAINABLE DEVELOPMENT GOALS, 2012, Transforming our world: the 2030 Agenda for Sustainable Development, New York.

42 ZAJĄC T., KLIMEK-KOPYRA A., OLEKSY A., LORENC-KOZIK A., RATAJCZAK K., 2016, Analysis of yield and planttraits of oilseed rape (Brassica napus L.) cultivated in temperate region in light possibilities of sowing in arid areas, in: Acta Agrobotanica, 69, p. 1696-1709.

43 ZAJĄC T., SYNOWIEC A., OLEKSY A., MACUDA J., KLIMEK-KOPYRA A., BOROWIEC F., 2017, Accumulation of biomass and bioenergy in culms of cereals as a factor of straw cutting height, in: International Agrophysics, 31, p. 273-285.

44 ZHANG X., LUO L., SKITMORE M., 2015, Household carbon emission research: an analytical review of measurement, influencing factors and mitigation prospects, in: Journal of Cleaner Production, 103, p. 873-883. 
